\title{
Beyond volutrauma in ARDS: the critical role of lung tissue deformation
}

\author{
Guillermo M Albaiceta,2* and Lluis Blanch ${ }^{2,3}$
}

\begin{abstract}
Ventilator-induced lung injury (VILI) consists of tissue damage and a biological response resulting from the application of inappropriate mechanical forces to the lung parenchyma. The current paradigm attributes VILI to overstretching due to very high-volume ventilation (volutrauma) and cyclic changes in aeration due to very low-volume ventilation (atelectrauma); however, this model cannot explain some research findings. In the present review, we discuss the relevance of cyclic deformation of lung tissue as the main determinant of VILI. Parenchymal stability resulting from the interplay of respiratory parameters such as tidal volume, positive end-expiratory pressure or respiratory rate can explain the results of different clinical trials and experimental studies that do not fit with the classic volutrauma/ atelectrauma model. Focusing on tissue deformation could lead to new bedside monitoring and ventilatory strategies.
\end{abstract}

\section{Introduction}

Mechanical ventilation is the cornerstone of treatment for acute lung injury (ALI) and the acute respiratory distress syndrome (ARDS). Like any other treatment, mechanical ventilation can also have adverse effects. Among these treatments, ventilator-induced lung injury (VILI) is one of the most studied. Since the first descriptions of the physical factors (pressure, volume, and so forth) involved in VILI, many mechanisms that promote lung injury - from lung mechanics to biochemical responses - have been identified [1], and ventilatory strategies aimed at reducing lung injury have been devised. The evidence for a clinical counterpart of VILI,

*Correspondence: Guillermo.muniz@sespa.princast.es

'Intensive Care Unit, Hospital Universitario Central de Asturias, Departamento de Biología Funcional, Universidad de Oviedo, Instituto Universitario de Oncología del Principado de Asturias (IUOPA), Celestino Villamil s/n, 33006 Oviedo, Spain Full list of author information is available at the end of the article which has been termed ventilator-associated lung injury, is more subtle, because the ventilatory settings are not as aggressive and the nature of lung injury in this case is always multifactorial [2]. Diverse clinical trials have studied the effects of protective ventilation strategies aimed at reducing ventilator-associated lung injury [313], but few studies have shown survival benefits $[4,8,10]$.

In the current paradigm of VILI, high positive endexpiratory pressure (PEEP) should be one of the most powerful strategies to decrease VILI [14]. Recently published trials have failed to show a clear benefit for high PEEP levels in a general population of patients with ALI and ARDS $[9,11,12]$. The mechanisms supposedly involved in VILI should therefore be reappraised to explain the failure of high PEEP levels and to design new therapeutic approaches to ALI/ARDS. The present article reviews the current paradigm of VILI and its limitations, and discusses additional explanations that can serve as a basis for the development of new strategies.

\section{The classic paradigm of ventilator-induced lung injury}

The classic paradigm of VILI maintains that there are two main physical triggers of lung injury during ventilation: overdistension of alveolar units (volutrauma) and cyclic changes in nonaerated lung (atelectrauma). High inspiratory lung volumes or pressures can cause injury through alveolar overdistension. Although there has been some debate about the primary force that causes injury, both volume and pressure are two sides of the same coin transpulmonary pressure. At the cellular level, stretching the lung beyond its capacity ruptures alveolar cell membranes [15], and the resulting cell death induces inflammation. Moreover, subtler injuries to the cytoskeleton or extracellular matrix trigger inflammation through intracellular signals [16].

The second mechanism of injury, cyclic changes in nonaerated lung, was deduced from the observation of lung injury during ventilation with low end-expiratory lung volume (EELV) or in the absence of PEEP. In this case, the mechanisms at the cellular level are less clear. Air bubbles flowing through a collapsed or fluid-filled airway might induce damage to the epithelium by 
generating a steep pressure gradient near the air bubble front [17]. A second consequence of low EELV can be a heterogeneous lung, and Mead and colleagues showed that the forces exerted on alveolar walls or septa in the interfaces between collapsed and aerated lung tissues can be amplified, leading to cell injury [18].

\section{Discrepancies with the model}

Some observations from experimental and clinical research do not fit with the classical paradigm. The application of PEEP is almost invariably associated with a decrease in VILI in different experimental models of lung injury, such as high tidal volume $(\mathrm{Vt})$ ventilation [14] or surfactant depletion [19]. When translating these models into clinical practice, a reduction in mortality has been found primarily in studies in which high PEEP is part of a greater strategy that includes low Vt $[4,10]$. Experimental designs combining high PEEP with low Vt make it impossible to clarify the contributions of each factor to the outcome. These clinical results are far from the sometimes impressive effects of PEEP seen in experimental models.

The effects of PEEP in healthy lungs also result in discrepancies with the paradigm. In intact lungs, one would expect PEEP to produce overdistension and a lack of significant cyclic recruitment; however, even in this setting, PEEP reduces VILI. One study showed that adding PEEP in intact rats ventilated with very high Vt could reduce injury [14]. These findings have a clinical correlate: a recent randomized trial showed in patients without lung injury that ventilation with PEEP did not worsen outcome, but improved oxygenation and decreased the risk of ventilator-associated pneumonia [20].

The effect of Vt on healthy lungs is also controversial. In experimental settings, a Vt of 10 to $15 \mathrm{ml} / \mathrm{kg}$ results in pressures of around 10 to $20 \mathrm{cmH}_{2} \mathrm{O}$ and can induce substantial damage in a short time [21]. A classic experiment from Mascheroni and colleagues demonstrated that, even in spontaneously breathing animals, chemically-induced hyperventilation could trigger substantial lung damage [22]. This work highlights the importance of tissue deformation, represented by increased transpulmonary pressures, even during negative-pressure ventilation (absence of high alveolar pressure, more homogeneous inflation). Again, the significance of these findings in clinical practice is not so clear. Studies that have addressed this issue in surgical patients have found no differences in the lung inflammatory response or outcome between low Vt or high Vt with short ventilatory times (from 1 to 3 hours) $[23,24]$, but found that high Vt increases proinflammatory mediators with longer ventilatory times [25-27]. Moreover, observational data $[28,29]$ and recent clinical trials $[30,31]$ suggest that high Vt increases the risk of acute lung injury in critically ill patients. The absence of specific markers of ventilator-associated lung injury precludes insight into the mechanisms underlying these results, but data from these articles suggest that Vt is important even in the absence of relevant recruitment/ derecruitment processes (as these were patients with healthy lungs) and overdistension (as pressures were below $30 \mathrm{cmH}_{2} \mathrm{O}$ ).

Low EELV has proved safe in both animals and patients, and this approach has sometimes been termed permissive atelectasis. In a recent study using an isolated lung model, Fanelli and colleagues demonstrated that permissive atelectasis caused the same amount of lung injury as the open lung strategy and only subtle differences in apoptosis and ultrastructural changes favoring the open lung strategy [32]. In the clinical setting, mortality rates in descriptive studies for patients managed with a low-pressure strategy are similar to those in clinical trials [33]. Taken together, these data contradict the volutrauma/atelectrauma model, suggesting that other mechanisms could be responsible for VILI.

\section{Alveolar instability and ventilator-induced lung injury}

Breathing, airflow, and blood flow exert complex mechanical forces on the lung that can be classified in specific physical terms: stress is the force per unit area; strain, also called stretch or deformation, is the change in length in relation to the initial length; and shear stress is the force per unit surface area in the direction of flow exerted at the fluid-surface interfaces. When applied to respiratory physiology, stress has been defined as transpulmonary pressure, and strain defined as the relationship between Vt and EELV. Although Gattinoni and colleagues have used the volume at zero PEEP as the reference EELV [34], it is not clear how recruitment (an increase in lung volume without increasing strain) can affect these measurements.

A series of mechanisms transform the lungs from a highly unstable structure (comparable with air bubbles in soap) into a very stable one. The surfactant system, alveolar interdependence, collateral ventilation, extracellular matrix, and mechanical properties of the chest wall work together to avoid alveolar collapse. These mechanisms guarantee a minimal resting volume (functional residual capacity/EELV) at end-expiration and a large number of alveoli to distribute each Vt. The net result is that healthy lungs present minimal changes in their structure during ventilation and only minor variations in alveolar size and shape. Using in vivo microscopy, several authors demonstrated that the change in size of subpleural alveoli is negligible when the total lung capacity remains between 10 and $80 \%[35,36]$, although substantial heterogeneity remained during 
alveolar expansion in normal lungs. Whereas some zones undergo only minimal changes in each breath, other zones undergo deformations of up to $20 \%$ of their length. This finding could have important consequences for VILI in healthy lungs.

Failure of any of the above-mentioned mechanisms leads to alveolar instability, understood as an excessive tissue deformation during each breath. Although this may be a vague term, and in fact the thresholds of stress and strain that lead to tissue injury are unknown, we will use it as a concept beyond the classic opening and closing hypothesis. In this sense, alveolar instability refers not only to tidal changes in aeration, but also to those circumstances of excessive lung tissue deformation irrespective of the alveolar initial status. This common mechanism could help to override the different hypothesis on lung injury induced by cyclic changes in lung aeration (that is, opening and closing of alveoli versus fluid and foam in airways and alveoli [37]). Most circumstances that increase alveolar instability also increase the risk of VILI. Whereas the current paradigm considers alveolar instability and VILI to be concomitant consequences of an unknown cause, we hypothesize that alveolar instability is the main mechanism in VILI. Lung injury increases alveolar instability, and alveolar damage starts in the unstable zones [19]; VILI could spread from these zones where tidal changes are more relevant. These zones are also present in healthy lungs, so this model could explain the induction of VILI in patients with and without previous lung injury.

Some studies have explored how ventilatory parameters influence lung deformation (Figure 1). Halter and colleagues demonstrated that changes in subpleural alveoli correlate directly to Vt and inversely to PEEP [38]. Interestingly, even with high Vt (up to $15 \mathrm{ml} / \mathrm{kg}$ ), increasing PEEP levels from 5 to $20 \mathrm{cmH}_{2} \mathrm{O}$ decreased alveolar instability from $108 \%$ to $15 \%$. Experiments performed in cells corroborate these findings. Using cell cultures submitted to cyclic stretch, Tschumperlin and colleagues showed that the magnitude of deformation was more important than the peak stretch in inducing cell death [39].

Excessive tissue deformation can also explain why healthy lungs ventilated with high Vt and moderate pressures develop lung injury. Vt promotes a timedependent increase in alveolar instability that could lead to lung damage [40]. Retrospective clinical studies have found that high Vt increases the risk of lung injury $[28,29]$, and a recent randomized clinical trial found a higher risk of ARDS with $10 \mathrm{ml} / \mathrm{kg}$ Vt than with $6 \mathrm{ml} / \mathrm{kg}$ Vt [30].

Considering alveolar instability as the main mechanism of VILI explains how PEEP may reduce VILI [38]. Even during ventilation with high Vt, PEEP can significantly reduce tidal changes in alveolar size. Valenza and

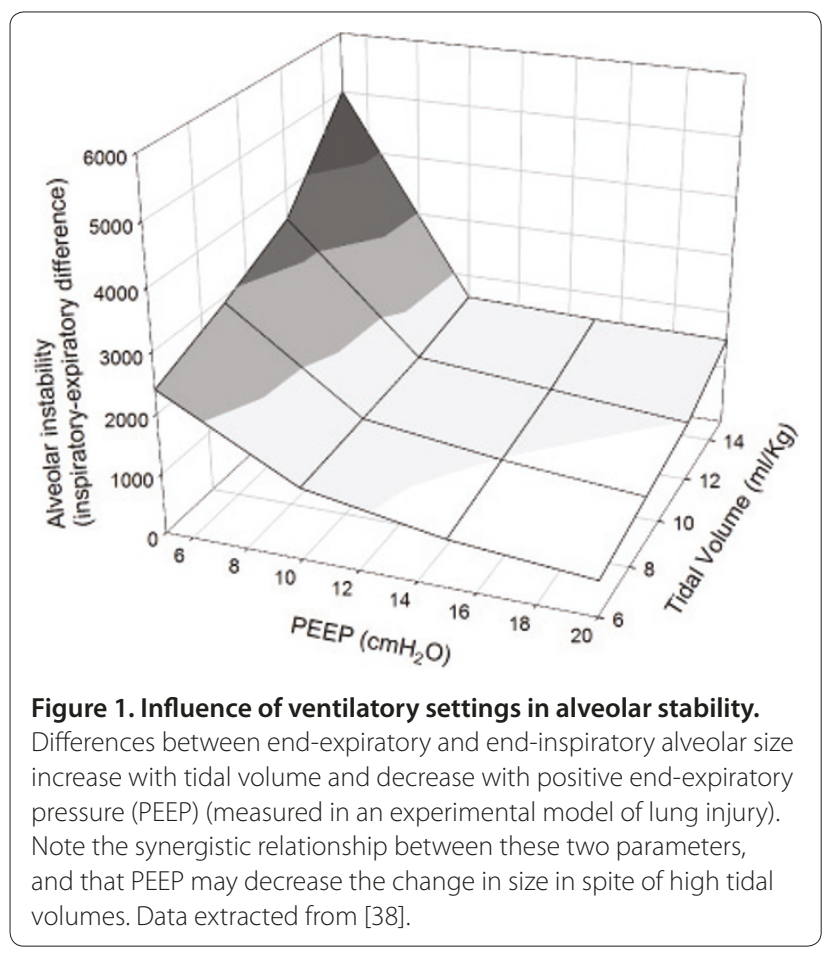

colleagues found that VILI was delayed in intact rats ventilated with high airway pressures and PEEP [14]. One could hypothesize that PEEP avoids the progressive impairment in alveolar stability, as seen during in vivo microscopy studies.

\section{Measurements of lung stability at the bedside}

Explained in terms of stress and strain, ventilation with moderate/high PEEP and low Vt will reduce both stress $(\mathrm{Vt})$ and strain (higher EELV induced by higher PEEP), thus reducing the risk of superimposed ventilator-associated lung injury. Terragni and colleagues found that even when Vt and plateau pressure are limited, patients with larger nonaerated lung compartments measured with computed tomography are exposed to tidal hyperinflation, with excessive lung deformation of the aerated compartment at each tidal breath [41]. Similarly, in patients with focal ARDS ventilated with the ARDSnet protocol, using a physiologic approach to PEEP setting based on the shape of the airway pressure curve as a function of time during constant flow attenuated alveolar hyperinflation [42]. Lack of lung recruitment with PEEP during protective lung ventilation is again associated with excessive lung deformation.

Chiumello and colleagues found that the plateau pressure and Vt were inadequate surrogates for lung stress and strain due to considerable overlap at both different Vt and PEEP values, and strain was clearly overestimated when recruitment was computed [34]. These results accounted for the high variability in functional 
residual capacity (a hallmark of ARDS) and the ratio of lung elastance to total respiratory system elastance. Experimental models in which relatively low pressures may induce severe injury, discussed in previous sections, also reinforce this inaccuracy of airway pressures and volumes to estimate tissue injury, due to differences in specific lung and chest wall elastances. In this setting, only surrogates of stress and strain may help to minimize the damage induced by ventilation. When lung recruitability was taken into account, however, reducing the amount of opening and closing lung tissue by increasing PEEP yielded benefits that prevailed over the harmful effects of increasing alveolar strain [43]. Interestingly, opening and closing lung tissue was distributed mainly in the dependent and hilar lung regions and appeared to be an independent risk factor for death.

\section{Reinterpreting the clinical trials}

The ARDSnet trial on Vt demonstrated that overall survival is higher using a Vt of $6 \mathrm{ml} / \mathrm{kg}$ than using a Vt of $12 \mathrm{ml} / \mathrm{kg}$ at similar levels of PEEP; that is, similar lung volume at end-expiration [8]. We would expect much greater lung deformation in patients ventilated with higher Vt. Lowering Vt therefore not only reduces overdistension, but also improves alveolar stability.

Despite the controversy on how much high transpulmonary pressure a patient with ARDS can tolerate for how long and the sustained clinical benefits of this approach, very high plateau pressure in patients with ALI/ARDS and normal chest wall compliance can inflict direct damage to the lungs or can aggravate existing disease. Nevertheless, recent trials have challenged the concept that mortality decreases directly with reductions in plateau pressure. Several studies tested the effect of two levels of PEEP on patients with ALI/ARDS ventilated with low Vt [9,11-13]. At equal Vt, high PEEP resulted in higher plateau pressure at end-inspiration compared with low PEEP. Interestingly, despite the significant differences in plateau pressures, no differences in mortality were observed, and only a trend toward lower mortality and fewer complications among ARDS patients was observed in the high PEEP group.

The benefits of high PEEP in ARDS patients were recently confirmed in a large systematic review and metaanalysis [44]. The patients included in these studies were exposed to similar stress, whereas strain depended on the previous effect of PEEP in the lung parenchyma (recruitment or overdistension). Figure 2 illustrates the differential effects of ventilatory parameters according to the presence of recruitment. In ALI/ARDS, the percentage of potentially recruitable lung is extremely variable and is strongly associated with the response to PEEP. This may also explain why the beneficial effects of PEEP are only seen in the most severe patients (that is, ARDS patients), in which recruitment and alveolar stabilization are the prevalent effects, whereas in those patients with mild injuries (ALI) this benefit is lost in the face of increased overstretching [44]. Unfortunately, prediction of the potentially recruitable lung using physiological variables that can be measured at the bedside is neither specific nor sensitive [45], and PEEP induces both recruitment and overdistension in most patients $[46,47]$.

\section{Increasing the complexity of the model}

Although the main focus of the present review is to explain how the classic concepts of volutrauma and atelectrauma can be unified by understanding the effects of ventilatory parameters on lung structure and alveolar instability, mechanical ventilation can also have effects beyond the lung.

Intrathoracic pressures have a strong effect on hemodynamics, and Vt and PEEP can modulate right ventricular function, with consequences for lung injury [48]. Studies in experimental models of isolated ventilated and perfused heart-lung blocks have demonstrated that the lung hemodynamics may interact with tidal ventilation to modulate lung injury [49]. Inflation of the lungs above their functional residual capacity results in an increase in pulmonary vascular resistance [50], and the increase in vascular resistance is largely the result of compression of the alveolar microcirculation by a tidal increase in alveolar pressure and thus in extramural pressure. Tidal alveolar vessel compression is opposed by the alveolar vessel intramural pressure, which, everything else being equal, varies in parallel with left atrial pressure. In other words, an increase in or a reduction in left atrial pressure, respectively, opposes or enhances the alveolar vessel compression from positive pressure ventilation [51]. Recent data have given credit to the concept that lung vessels exposed to injurious ventilatory patterns behave like material prone to fatigue and failure in similar experimental conditions. It thus appears that both high and low capillary pressures are best avoided to limit the risk of VILI [49,51]. Moreover, these effects are aggravated by ventilation at rapid respiratory rates with concomitant increases of pulmonary artery pressure [52] and in conditions of high cardiac output $[53,54]$. In this context, PEEP serves to diminish transmural pressure (decreases strain) and attenuates edema formation and lung hemorrhage [48]. These data highlight the interactive nature of the processes and cofactors in the modulation of VILI-like global and/or regional pulmonary hemodynamics; the presence, type, and timing of secondary lung insults; and interactions between regional heterogeneity of pulmonary perfusion and regionally heterogeneous peak airspace strains. Lastly, these vascular variables also hint at potential difficulties in designing appropriate trials of lung-protective ventilatory strategies. 


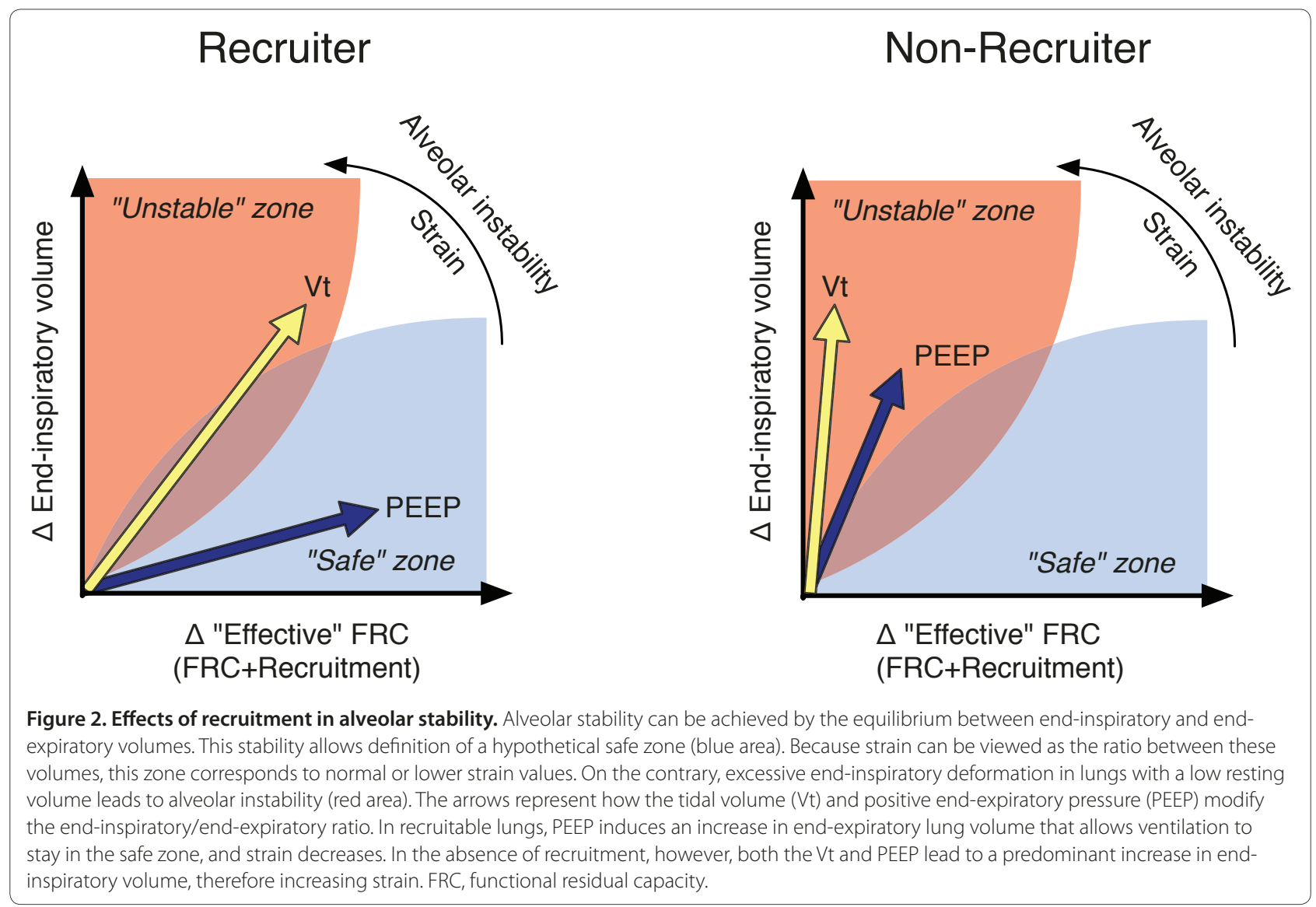

Furthermore, mechanical ventilation can influence both local and systemic immune responses [1] because mechanical forces within the lungs trigger different biological responses that spread into the systemic circulation. Although much knowledge about this issue has been generated in recent years, the specific contribution of ventilator settings to the inflammatory response (that is, the biological activity brought about increasing volutrauma or atelectrauma) is unknown, and this complex response is likely to be influenced by patients' baseline conditions.

\section{Conclusions}

Knowledge of the mechanisms involved in VILI is important to develop ventilatory strategies that could result in clinical benefits. Recent advances suggest that isolated mechanical forces (plateau pressure, PEEP) cannot adequately explain VILI; rather, the amount of damage depends on the simultaneous interaction of these forces and the previous status of the lung parenchyma. Ultimately, dynamic changes in alveolar structure could be responsible for lung injury. The translation of these concepts to the bedside requires complex physiological reasoning and directed research.

\section{Competing interests}

The authors declare that they have no competing interests.

\section{Abbreviations}

ALI, acute lung injury; ARDS, acute respiratory distress syndrome; EELV, endexpiratory lung volume; PEEP, positive end-expiratory pressure; VILI, ventilatorinduced lung injury; $V t$, tidal volume.

\section{Author details}

IIntensive Care Unit, Hospital Universitario Central de Asturias, Departamento de Biología Funcional, Universidad de Oviedo, Instituto Universitario de Oncología del Principado de Asturias (IUOPA), Celestino Villamil s/n, 33006 Oviedo, Spain. ${ }^{2}$ CIBER de Enfermedades Respiratorias, Instituto de Salud Carlos III, Spain. ${ }^{3}$ Critical Care Center, Hospital de Sabadell, Corporació Parc Taulí, Insitut Universitari Fundació Parc Tauli, Universitat Autònoma de Barcelona, Parc Taulí s/n, 08208 Sabadell, Spain

Published: 7 April 2011

\section{References}

1. dos Santos CC, Slutsky AS: The contribution of biophysical lung injury to the development of biotrauma. Annu Rev Physiol 2006, 68:585-618.

2. International consensus conferences in intensive care medicine. Ventilator-associated lung injury in ARDS. American Thoracic Society, European Society of Intensive Care Medicine, Societe de Reanimation Langue Francaise. Intensive Care Med 1999, 25:1444-1452.

3. Brower RG, Shanholtz CB, Fessler HE, Shade DM, White P, Jr, Wiener CM, Teeter JG, Dodd-o JM, Almog Y, Piantadosi S: Prospective, randomized, controlled clinical trial comparing traditional versus reduced tidal volume ventilation in acute respiratory distress syndrome patients. Crit Care Med 1999, 27:1492-1498. 
4. Amato MB, Barbas CS, Medeiros DM, Magaldi RB, Schettino GP, Lorenzi-Filho G, Kairalla RA, Deheinzelin D, Munoz C, Oliveira R, Takagaki TY, Carvalho CR: Effect of a protective-ventilation strategy on mortality in the acute respiratory distress syndrome. N Engl J Med 1998, 338:347-354.

5. Brochard L, Roudot-Thoraval F, Roupie E, Delclaux C, Chastre J, FernandezMondejar E, Clementi E, Mancebo J, Factor P, Matamis D, Ranieri M, Blanch L, Rodi G, Mentec H, Dreyfuss D, Ferrer M, Brun-Buisson C, Tobin M, Lemaire F: Tidal volume reduction for prevention of ventilator-induced lung injury in acute respiratory distress syndrome. The Multicenter Trail Group on Tidal Volume reduction in ARDS. Am J Respir Crit Care Med 1998, 158:1831-1838.

6. Stewart TE, Meade MO, Cook DJ, Granton JT, Hodder RV, Lapinsky SE, Mazer CD, McLean RF, Rogovein TS, Schouten BD, Todd TR, Slutsky AS: Evaluation of a ventilation strategy to prevent barotrauma in patients at high risk for acute respiratory distress syndrome. Pressure- and Volume-Limited Ventilation Strategy Group. N Engl J Med 1998, 338:355-361.

7. Ranieri VM, Suter PM, Tortorella C, De Tullio R, Dayer JM, Brienza A, Bruno F, Slutsky AS: Effect of mechanical ventilation on inflammatory mediators in patients with acute respiratory distress syndrome: a randomized controlled trial. JAMA 1999, 282:54-61

8. Ventilation with lower tidal volumes as compared with traditional tidal volumes for acute lung injury and the acute respiratory distress syndrome. The Acute Respiratory Distress Syndrome Network. N Engl J Med 2000, 342:1301-1308.

9. Brower RG, Lanken PN, Maclntyre N, Matthay MA, Morris A, Ancukiewicz M, Schoenfeld D, Thompson BT: Higher versus lower positive end-expiratory pressures in patients with the acute respiratory distress syndrome. N Engl J Med 2004, 351:327-336.

10. Villar J, Kacmarek RM, Perez-Mendez L, Aguirre-Jaime A: A high positive end-expiratory pressure, low tidal volume ventilatory strategy improves outcome in persistent acute respiratory distress syndrome: a randomized, controlled trial. Crit Care Med 2006, 34:1311-1318.

11. Mercat A, Richard JC, Vielle B, Jaber S, Osman D, Diehl JL, Lefrant JY, Prat G, Richecoeur J, Nieszkowska A, Gervais C, Baudot J, Bouadma L, Brochard L: Positive end-expiratory pressure setting in adults with acute lung injury and acute respiratory distress syndrome: a randomized controlled trial. JAMA 2008, 299:646-655.

12. Meade MO, Cook DJ, Guyatt GH, Slutsky AS, Arabi YM, Cooper DJ, Davies AR, Hand LE, Zhou Q, Thabane L, Austin P, Lapinsky S, Baxter A, Russell J, Skrobik Y, Ronco JJ, Stewart TE: Ventilation strategy using low tidal volumes, recruitment maneuvers, and high positive end-expiratory pressure for acute lung injury and acute respiratory distress syndrome: a randomized controlled trial. JAMA 2008, 299:637-645.

13. Talmor D, Sarge T, Malhotra A, O'Donnell CR, Ritz R, Lisbon A, Novack V, Loring $\mathrm{SH}$ : Mechanical ventilation guided by esophageal pressure in acute lung injury. N Engl J Med 2008, 359:2095-2104

14. Valenza F, Guglielmi M, Irace M, Porro GA, Sibilla S, Gattinoni L: Positive endexpiratory pressure delays the progression of lung injury during ventilator strategies involving high airway pressure and lung overdistention. Crit Care Med 2003, 31:1993-1998.

15. Vlahakis NE, Hubmayr RD: Cellular stress failure in ventilator-injured lungs. Am J Respir Crit Care Med 2005, 171:1328-1342.

16. Ridge KM, Linz L, Flitney FW, Kuczmarski ER, Chou YH, Omary MB, Sznajder Jl, Goldman RD: Keratin 8 phosphorylation by protein kinase $C$ delta regulates shear stress-mediated disassembly of keratin intermediate filaments in alveolar epithelial cells. J Biol Chem 2005, 280:30400-30405.

17. Bilek AM, Dee KC, Gaver DP, 3rd: Mechanisms of surface-tension-induced epithelial cell damage in a model of pulmonary airway reopening. J Appl Physiol 2003, 94:770-783.

18. Mead J, Takishima T, Leith D: Stress distribution in lungs: a model of pulmonary elasticity. J App/ Physio/ 1970, 28:596-608.

19. Steinberg JM, Schiller HJ, Halter JM, Gatto LA, Lee HM, Pavone LA, Nieman GF: Alveolar instability causes early ventilator-induced lung injury independent of neutrophils. Am J Respir Crit Care Med 2004, 169:57-63.

20. Manzano F, Fernandez-Mondejar E, Colmenero M, Poyatos ME, Rivera R, Machado J, Catalan I, Artigas A: Positive-end expiratory pressure reduces incidence of ventilator-associated pneumonia in nonhypoxemic patients. Crit Care Med 2008, 36:2225-2231

21. Wolthuis EK, Vlaar AP, Choi G, Roelofs JJ, Juffermans NP, Schultz MJ: Mechanical ventilation using non-injurious ventilation settings causes lung injury in the absence of pre-existing lung injury in healthy mice. Crit Care 2009, 13:R1.
22. Mascheroni D, Kolobow T, Fumagalli R, Moretti MP, Chen V, Buckhold D: Acute respiratory failure following pharmacologically induced hyperventilation: an experimental animal study. Intensive Care Med 1988, 15:8-14.

23. Wrigge $H$, Uhlig U, Zinserling J, Behrends-Callsen E, Ottersbach G, Fischer M, Uhlig S, Putensen C: The effects of different ventilatory settings on pulmonary and systemic inflammatory responses during major surgery. Anesth Analg 2004, 98:775-781.

24. Wrigge H, Zinserling J, Stuber F, von Spiegel T, Hering R, Wetegrove S, Hoeft A, Putensen C: Effects of mechanical ventilation on release of cytokines into systemic circulation in patients with normal pulmonary function. Anesthesiology 2000, 93:1413-1417.

25. Michelet P, D'Journo XB, Roch A, Doddoli C, Marin V, Papazian L, Decamps I, Bregeon F, Thomas P, Auffray JP: Protective ventilation influences systemic inflammation after esophagectomy: a randomized controlled study. Anesthesiology 2006, 105:911-919.

26. Wrigge H, Uhlig U, Baumgarten G, Menzenbach J, Zinserling J, Ernst M Dromann D, Welz A, Uhlig S, Putensen C: Mechanical ventilation strategies and inflammatory responses to cardiac surgery: a prospective randomized clinical trial. Intensive Care Med 2005, 31:1379-1387.

27. Schilling T, Kozian A, Huth C, Buhling F, Kretzschmar M, Welte T, Hachenberg T: The pulmonary immune effects of mechanical ventilation in patients undergoing thoracic surgery. Anesth Analg 2005, 101:957-965.

28. Gajic O, Frutos-Vivar F, Esteban A, Hubmayr RD, Anzueto A: Ventilator settings as a risk factor for acute respiratory distress syndrome in mechanically ventilated patients. Intensive Care Med 2005, 31:922-926.

29. Gajic O, Dara SI, Mendez JL, Adesanya AO, Festic E, Caples SM, Rana R, St Sauver JL, Lymp JF, Afessa B, Hubmayr RD: Ventilator-associated lung injury in patients without acute lung injury at the onset of mechanical ventilation. Crit Care Med 2004, 32:1817-1824.

30. Determann RM, Royakkers A, Wolthuis EK, Vlaar AP, Choi G, Paulus F, Hofstra JJ, de Graaff MJ, Korevaar JC, Schultz MJ: Ventilation with lower tidal volumes as compared with conventional tidal volumes for patients without acute lung injury: a preventive randomized controlled trial. Crit Care 2010, 14:R1.

31. Pinheiro de Oliveira R, Hetzel MP, Dos Anjos Silva M, Dallegrave D, Friedman $\mathrm{G}$ : Mechanical ventilation with high tidal volume induces inflammation in patients without lung disease. Crit Care 2010, 14:R39.

32. Fanelli V, Mascia L, Puntorieri V, Assenzio B, Elia V, Fornaro G, Martin EL, Bosco M, Delsedime L, Fiore T, Grasso S, Ranieri VM: Pulmonary atelectasis during low stretch ventilation: 'open lung' versus 'lung rest' strategy. Crit Care Med 2009, 37:1046-1053.

33. Page B, Vieillard-Baron A, Beauchet A, Aegerter P, Prin S, Jardin F: Low stretch ventilation strategy in acute respiratory distress syndrome: eight years of clinical experience in a single center. Crit Care Med 2003, 31:765-769.

34. Chiumello D, Carlesso E, Cadringher P, Caironi P, Valenza F, Polli F, Tallarini F, Cozzi P, Cressoni M, Colombo A, Marini JJ, Gattinoni L: Lung stress and strain during mechanical ventilation for acute respiratory distress syndrome. Am J Respir Crit Care Med 2008, 178:346-355.

35. Carney DE, Bredenberg CE, Schiller HJ, Picone AL, McCann UG, Gatto LA, Bailey G, Fillinger M, Nieman GF: The mechanism of lung volume change during mechanical ventilation. Am J Respir Crit Care Med 1999, 160(5 Pt 1):1697-1702.

36. Perlman CE, Bhattacharya J: Alveolar expansion imaged by optical sectioning microscopy. J App/ Physio/ 2007, 103:1037-1044.

37. Hubmayr RD: Perspective on lung injury and recruitment: a skeptical look at the opening and collapse story. Am J Respir Crit Care Med 2002 165:1647-1653.

38. Halter JM, Steinberg JM, Gatto LA, DiRocco JD, Pavone LA, Schiller HJ, Albert S, Lee HM, Carney D, Nieman GF: Effect of positive end-expiratory pressure and tidal volume on lung injury induced by alveolar instability. Crit Care 2007, 11:R20.

39. Tschumperlin DJ, Oswari J, Margulies AS: Deformation-induced injury of alveolar epithelial cells. Effect of frequency, duration, and amplitude. Am Respir Crit Care Med 2000, 162(2 Pt 1):357-362.

40. Pavone LA, Albert S, Carney D, Gatto LA, Halter JM, Nieman GF: Injurious mechanical ventilation in the normal lung causes a progressive pathologic change in dynamic alveolar mechanics. Crit Care 2007, 11:R64.

41. Terragni PP, Rosboch G, Tealdi A, Corno E, Menaldo E, Davini O, Gandini G, Herrmann P, Mascia L, Quintel M, Slutsky AS, Gattinoni L, Ranieri VM: Tidal hyperinflation during low tidal volume ventilation in acute respiratory distress syndrome. Am J Respir Crit Care Med 2007, 175:160-166.

42. Grasso S, Stripoli T, De Michele M, Bruno F, Moschetta M, Angelelli G, Munno I, 
Ruggiero V, Anaclerio R, Cafarelli A, Driessen B, Fiore T: ARDSnet ventilatory protocol and alveolar hyperinflation: role of positive end-expiratory pressure. Am J Respir Crit Care Med 2007, 176:761-767.

43. Caironi P, Cressoni M, Chiumello D, Ranieri M, Quintel M, Russo SG, Cornejo R, Bugedo G, Carlesso E, Russo R, Caspani L, Gattinoni L: Lung opening and closing during ventilation of acute respiratory distress syndrome. $\mathrm{Am}\rfloor$ Respir Crit Care Med 2009, 181:578-586.

44. Briel M, Meade M, Mercat A, Brower RG, Talmor D, Walter SD, Slutsky AS, Pullenayegum E, Zhou Q, Cook D, Brochard L, Richard JC, Lamontagne F, Bhatnagar N, Stewart TE, Guyatt G: Higher vs lower positive end-expiratory pressure in patients with acute lung injury and acute respiratory distress syndrome: systematic review and meta-analysis. JAMA 2010, 303:865-873.

45. Gattinoni L, Caironi P, Cressoni M, Chiumello D, Ranieri VM, Quintel M, Russo S, Patroniti N, Cornejo R, Bugedo G: Lung recruitment in patients with the acute respiratory distress syndrome. N Eng/ J Med 2006, 354:1775-1786.

46. Albaiceta GM, Taboada F, Parra D, Luyando LH, Calvo J, Menendez R, Otero J: Tomographic study of the inflection points of the pressure-volume curve in acute lung injury. Am J Respir Crit Care Med 2004, 170:1066-1072.

47. Albaiceta GM, Luyando LH, Parra D, Menendez R, Calvo J, Pedreira PR, Taboada F: Inspiratory vs. expiratory pressure-volume curves to set endexpiratory pressure in acute lung injury. Intensive Care Med 2005, 31:1370-1378

48. Piacentini E, Lopez-Aguilar J, Garcia-Martin C, Villagra A, Saenz-Valiente A, Murias G, Fernandez-Segoviano P, Hotchkiss JR, Blanch L: Effects of vascular flow and PEEP in a multiple hit model of lung injury in isolated perfused rabbit lungs. J Trauma 2008, 65:147-153.
49. Marini JJ, Hotchkiss JR, Broccard AF: Bench-to-bedside review: microvascular and airspace linkage in ventilator-induced lung injury. Crit Care 2003, 7:435-444.

50. Fu Z, Costello ML, Tsukimoto K, Prediletto R, Elliott AR, Mathieu-Costello O, West JB: High lung volume increases stress failure in pulmonary capillaries. J Appl Physiol 1992, 73:123-133.

51. Broccard AF, Vannay C, Feihl F, Schaller MD: Impact of low pulmonary vascular pressure on ventilator-induced lung injury. Crit Care Med 2002, 30:2183-2190.

52. Hotchkiss JR, Jr, Blanch L, Murias G, Adams AB, Olson DA, Wangensteen OD, Leo $\mathrm{PH}$, Marini JJ: Effects of decreased respiratory frequency on ventilatorinduced lung injury. Am J Respir Crit Care Med 2000, 161 (2 Pt 1):463-468.

53. Lopez-Aguilar J, Piacentini E, Villagra A, Murias G, Pascotto S, Saenz-Valiente A, Fernandez-Segoviano P, Hotchkiss JR, Blanch L: Contributions of vascular flow and pulmonary capillary pressure to ventilator-induced lung injury. Crit Care Med 2006, 34:1106-1112.

54. Broccard AF, Hotchkiss JR, Kuwayama N, Olson DA, Jamal S, Wangensteen DO, Marini JJ: Consequences of vascular flow on lung injury induced by mechanical ventilation. Am J Respir Crit Care Med 1998, 157(6 Pt 1):1935-1942.

doi:10.1186/cc10052

Cite this article as: Albaiceta GM, Blanch L: Beyond volutrauma in ARDS: the critical role of lung tissue deformation. Critical Care 2011, 15:304. 